\title{
千葉県柏市における土塞中放射性セシウムの 深度・水平分布に係る実態調査
}

\author{
市川有二郎 ${ }^{\dagger}$, 井上智博, 内藤季和，田中 勉，高橋良彦
}

\author{
千葉県環境研究センター \\ 290-0046 千葉県市原市岩崎西 1-8-8 \\ 'y.ichkw17@pref.chiba.lg.jp
}

\begin{abstract}
降雨による土壌中の放射性セシウムの移行状況を確認するために, 2013 年度の梅雨期前後と台 風後の千葉県柏市内の土壤を対象に調查した。本調查は, 福島原発事故から約 $2 \sim 3$ 年後に行われ たが，地表面から深さ $5 \mathrm{~cm}$ 以内に $95 \%$ 以上の放射性セシウムが含まれ，降雨による放射性セシ ウムの鉛直方向への浸透はほとんど進行していないことが示唆された。水平分布については，同一 敷地内でも最大で $2 \sim 3$ 倍程度の差があることが確認された。本調査では, 放射性セシウム濃度が 明確な粒径依存性を示さなかったが，関東ロームの特異性が影響している可能性がある。
\end{abstract}

\begin{abstract}
Key Words : Fukushima Daiichi Nuclear Power Plant Accident, Kashiwa City, radioactive caesium, soil, vertical distribution, horizontal distribution, particle size distribution, Kanto Loam
\end{abstract}

\section{1. はじめに}

2011 年 3 月 11 日の東日本大震災に伴う東京 電力福島第一原子力発電所 (以下,「福島原発」 とする。）事故により放射性物質が一般環境に 放出され，重大な環境污染をもたらした。国か らの委託研究として日本原子力研究開発機構を はじめとした様々な大学や研究機関が継続的に 行っている「放射性物質の分布状況等に関する 調査」(以下，「分布状況等調查」とする。）では, 福島原発事故に伴う放射性物質の移行メカニズ ムの詳細を明らかにすることで，放射性物質に よる長期的影響を把握することを目的としてお り, 様々な環境媒体を対象とした包括的な調查 が遂行され，これまでの調査結果は報告書とし てまとめられている(1)-4)。だが, 分布状況等調 查では, 福島県内での調查が中心であり, その 近隣県等での知見はわずかである。

千葉県北西部の東葛飾地域で国から污染状況 重点調查地域として指定を受けている柏市, 松
戸市，野田市，流山市，我孫子市は東京都心か ら $20 \mathrm{~km} \sim 40 \mathrm{~km}$ 圈内に含まれ，鉄道や専用 道路等の交通網が発達し, 首都圈への通勤や通 学の利便性も高いことから都市化が進んだ地域 (以下,「都市部」とする。)である。このよう な都市部では, 分布状況等調查で実施されてい る福島県内の調查地（以下，比較のため「非都 市部」とする。）に比べてまちづくりの形態や 土地利用状況が異なるため, 放射性物質の移行 特性も異なる可能性がある。また, 多くの人口 が集中する都市部における放射性物質の動態解 明は，住民の被ばく低隇施策や関係機関が実施 する対策のためにも哭緊の課題である。

福島原発事故から 2 年以上が経過（本調查開 始日の 2013 年 5 月 23 日から換算) し, 除染作 業やウェザリング効果 (風雨などの自然要因に よる放射性物質の洗い流し）によって千葉県内 の空間線量率は低減・安定化しつつある。しか し, 環境省 ${ }^{5)}$-15) や千葉県 ${ }^{16)-23)}$ が千葉県北西部 を流域に含む利根川水系の湖沼である手賀沼と 
その周辺河川で実施している放射能モニタリン グ調査結果 (Fig. 1)によると，底泥中放射性セ シウム濃度 $\left({ }^{134} \mathrm{Cs}+{ }^{137} \mathrm{Cs}\right)$ は減少傾向を示して いるものの，依然として $1000 \mathrm{~Bq} / \mathrm{kg}$ （乾）を 超える濃度が確認されており，その上流域から 放射性セシウムが供給されていることが考えら れる。なお，以下本報では放射性物質の代表と して放射性セシウムのみを取扱う。

福島原発よりフォールアウトした放射性セシ ウムは，水や土壤など様々な環境媒体中に存在 し，比較的低濃度であっても非常に広範囲に拡 散しているため，その動態を把握するためには 多面的な検討が必要である。著者らは，手賀沼 流域の大堀川を流末とする柏市内の調整池を調 查場所とし, 周辺環境（後背地）から調整池へ の放射性セシウムの移行状況及び調整池からの 流出状況を推定することで，放射性セシウムの 蓄積・消長を定量評価し，千葉県北西部の都市 部における放射性セシウムの動態を検証するた めに調査を行っている。

本報では，当該調査で得られた土壤中におけ る放射性セシウムの測定・解析結果について報 告をする。当該調查を通じて，県民の被ばく低 減施策や関係機関が実施する調查・対策への技 術的支援に資することを目的としている。

\section{2. 調 査 概 要}

\section{$2 \cdot 1$ 調查場所}

環境省 ${ }^{5)}$-15)，千葉県 ${ }^{16)}$-23) が実施した手賀沼 流域の放射能モニタリング調査において，手賀 沼とその流域河川の大堀川や大津川で特に高い 放射性セシウム濃度を有する底泥が確認されて いる。そこで, Fig. 2 に示した大堀川本川へ流 入する柏市内の雨水調整池「柏の葉第 1 号調整 池（以下，「柏 $1 」$ とする。）」，「柏の葉第 2 号 調整池（以下，「柏 $2 」$ とる。）」，「松ヶ崎第 10 調整池（以下，「松 10」とする。)」の 3 か所 を調查場所に選定した。各調整池の敷地内で， 人が立入らず，除染作業が実施されていない $100 \sim 150 \mathrm{~m}^{2}$ 程度の区域を土壤採取場所に選
定した。

なお，上記 3 か所の雨水調整池は，掘込式の オンサイト貯留施設となっており，局地的な降 雨などに備えて下流域における水害を未然に防 止するために設置されている。各調整池からの 放水量は，原則的に一定量となるように調節さ れており，調整池が冠水したり干上がらないよ うに設計されている。

\section{$2 \cdot 2$ 調查時期}

降水による放射性セシウムの移行状況を確認 するために梅雨期前後と台風後に調査時期を設 定した。具体的な梅雨前，梅雨後，台風後の調 査日は，それぞれ 2013 年 5 月 23 日， 7 月 12 日，11月 27 日であった。

気象庁の発表によると 2013 年の関東甲信地 方の梅雨入りは 6 月 10 日ごろで，梅雨明けは 7 月 6 日ごろであった。我孫子観測所は柏市か ら最寄りのアメダス観測所であり，梅雨期間の 降水量は $182 \mathrm{~mm}$ であった ${ }^{24)}$ 。たた 2013 年 10 月 16 日午前に 10 年に 1 度の規模といわれ る大型台風第 26 号 Wipha が関東地方に接近し, 各地域に甚大な被害をもたらした ${ }^{25)}$ 。我孫子観 測所でも，16 日のわずか 1 日間で $196.5 \mathrm{~mm}$ という記録的な降水量となった ${ }^{24)}$ 。

\section{$2 \cdot 3$ 土袞のサンプリング}

各調整池の土壤採取区域内の 3 か所で Fig. 3 のようなハンドサンプラー（藤原製作所 HS-25, $\phi 50 \times 300 \mathrm{~mm} ）$ にポリ塩化ビニル製円筒管を 装着して土壤をコア状に採取した。土䁃は，形 が崩れないように注意しコア状のまま $-30^{\circ} \mathrm{C}$ で冷凍保存した。土壌中放射性セシウム濃度の 深度分布を調べるために，冷凍状態のコア状土 壤を地表面から $0 \sim 1 \mathrm{~cm}, 1 \sim 2 \mathrm{~cm}, 2 \sim 3 \mathrm{~cm}$, $3 \sim 4 \mathrm{~cm}, 4 \sim 5 \mathrm{~cm}, 5 \sim 7 \mathrm{~cm}, 7 \sim 10 \mathrm{~cm}$ の層に切り分け, $105^{\circ} \mathrm{C}$ で 24 時間乾燥させた。 その後， $2 \mathrm{~mm}$ メッシュのステンレス製ふるい に通過させて得た土壤を十分混合し， $100 \mathrm{~mL}$ のU-8 容器に隙間無く充填し分析用試料とし 
(a)

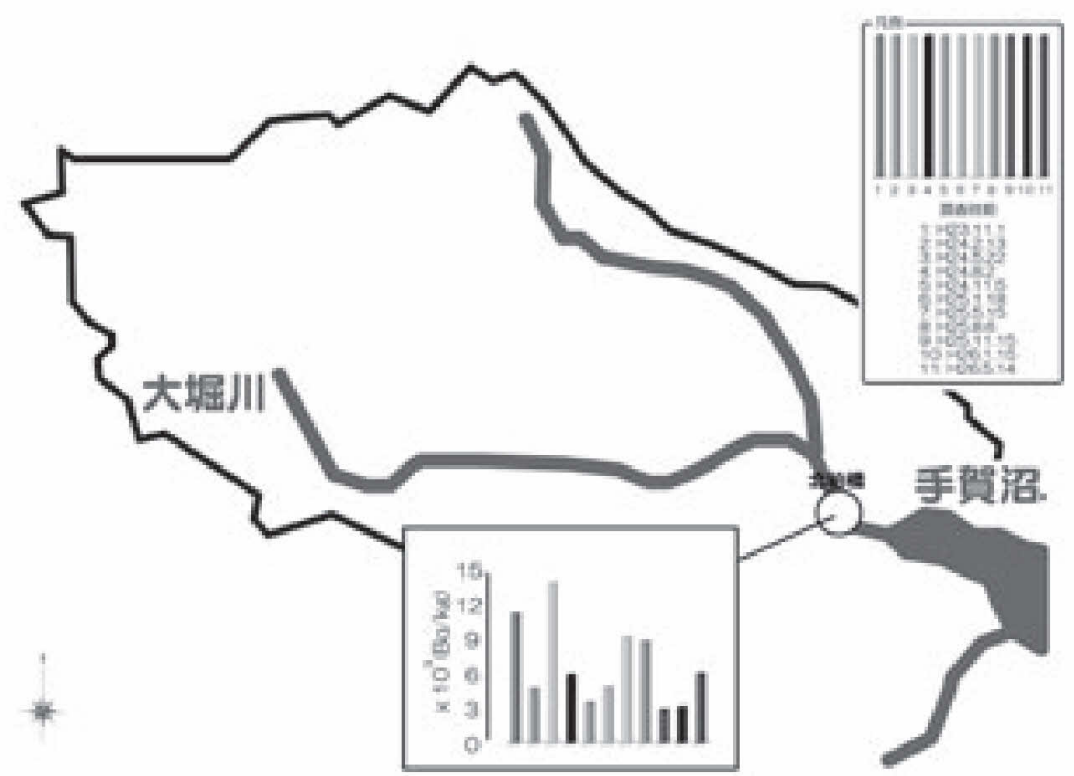

(b)

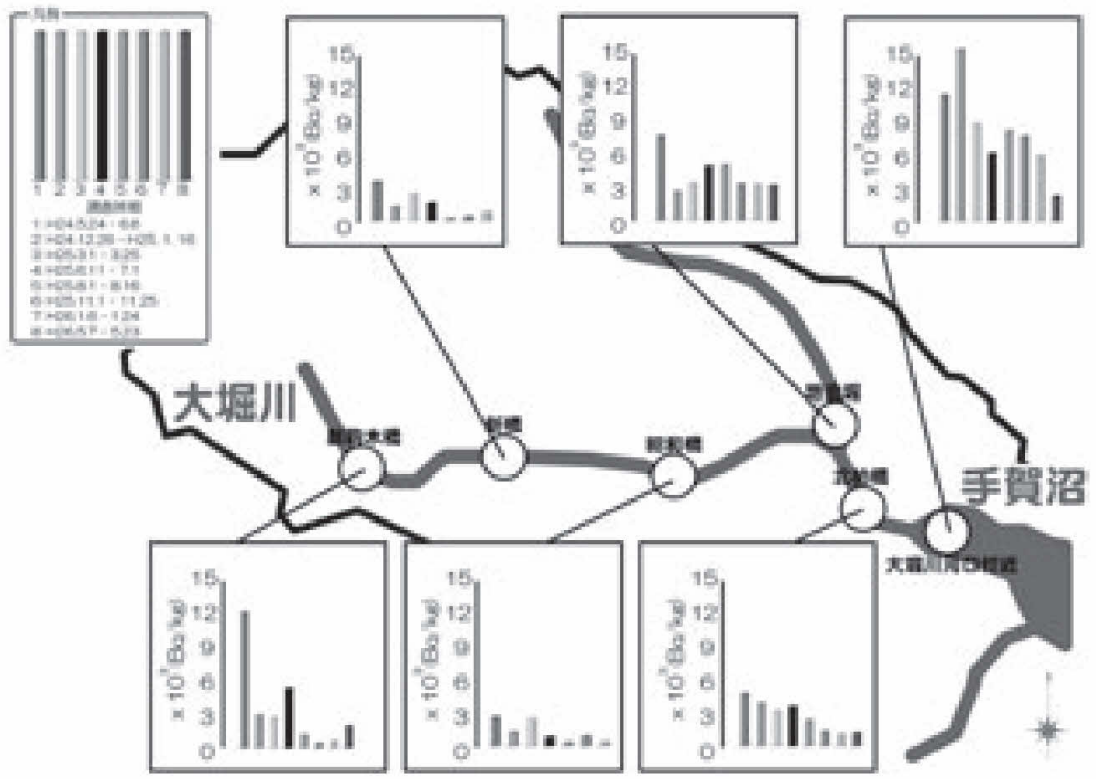

（注）新橋、昭和橋では H26.5.7 - 5.23 の調查は実施していない。

Fig. 1 手賀沼へ流入する大堀川で計測された底泥中放射性セシウム濃度。（a）環境省 の調查結果 $\left.{ }^{5)}-15\right) ，(b)$ 千葉県の調查結果 ${ }^{16)}$-23)

た。なお, 各調整池では, 植生等の無い裸地で の土壌採取を試みたが，柏 2 では採取区域が芝 地であったため，可能な限り芝が植わっていな
い場所で土畩を採取し，前処理時に目視で混入 した芝をピンセットで取り除いた。

梅雨前に測定した土壤中放射性セシウム濃度 


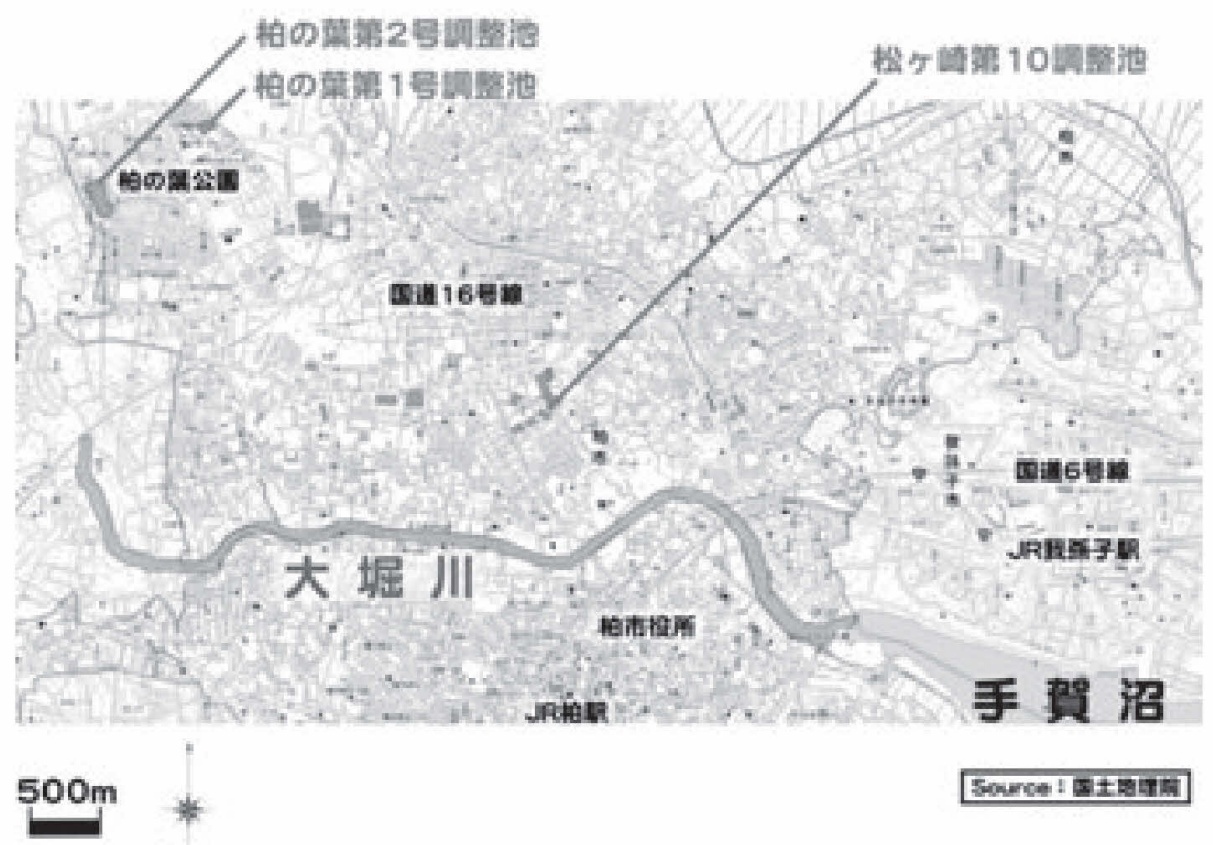

Fig. 2 調查場所である各調整池，大堀川と手賀沼の位置関係
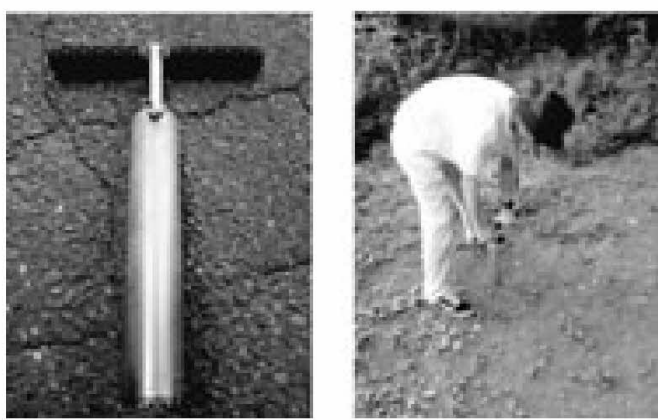

Fig. 3 ハンドサンプラーによる土壤採取

については，各調整池敷地内で採取した 3 試料 の土壤をそれぞれ上記の深度幅で切り分けた後 に，各層を混合したものをゲルマニウム半導体 検出器で分析した。一方で，それ以外の調査時 期にサンプリングした土壤試料については，採 取した 3 試料を個々に深度別放射性セシウム濃 度の測定を行い，深度特性のばらつき等の評価 も行った。
$2 \cdot 4$ ゲルマニウム半導体検出器の測定条件 試料の分析は，数種類の標準線源が含まれた 試料によって校正されたゲルマニウム半導体検 出器（キャンベラ社製 GC 2520 , 分解能 : 放射 性核種 ${ }^{60} \mathrm{Co}$ のピークエネルギー $1332 \mathrm{keV}$ に対 する半值幅は $1.75 \mathrm{keV}$, 相対効率 : $32.9 \%$ ) で行い， $\gamma$ 線スペクトロメトリに ${ }^{134} \mathrm{Cs}$ (定量ピ ーク：605 keV）及 び137 $\mathrm{Cs}(662 \mathrm{keV})$ の放射 性セシウムを定量した。各分析試料の採取日時 に滅衰補正し，また自己吸収補正及びサムピー ク補正も行った。

\section{$2 \cdot 5$ 粒径分布の測定}

放射性セシウム濃度と土壌粒子の粒径に相関 性があるかを調べるために，深度別放射性セシ ウム濃度の測定が完了した各調查場所で採取し た土壤試料を用いた。0〜 $5 \mathrm{~cm}$ までの層の土 壤試料を放射能測定に必要な土壤重量を得るた めに十分混合し，Fig. 4 に示した振動式ふるい 機（伊藤製作所 FRITSCH Analysette）を用い た乾式ふるい法で分級し，各々の放射性セシウ 

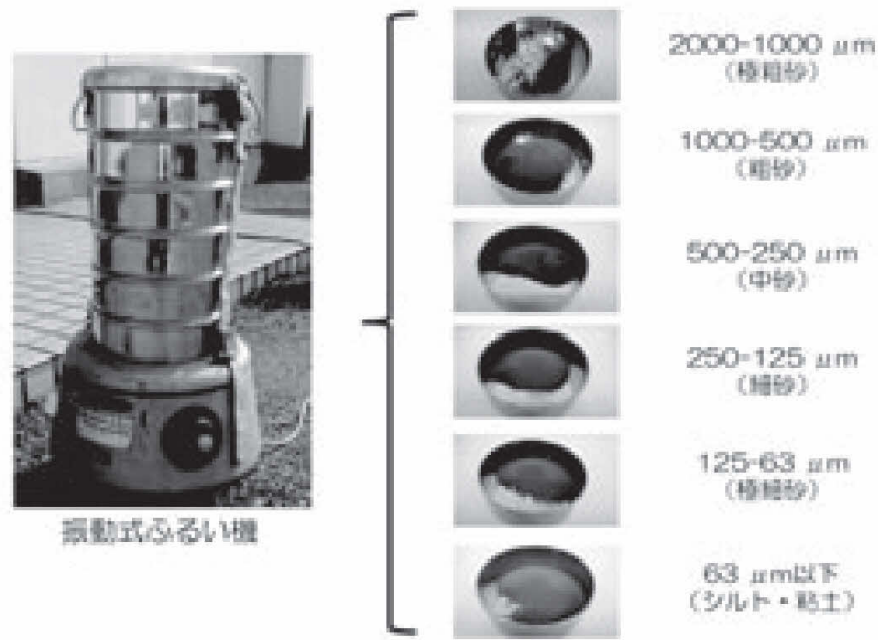

Fig. 4 土壤の分級に使用した振動式ふるい機

ム濃度を測定した。分級幅は, $2.0 \mathrm{~mm} \sim 1.0$ $\mathrm{mm}$ (極粗砂), $1.0 \mathrm{~mm} \sim 500 \mu \mathrm{m}$ (粗砂), 500 $\mu \mathrm{m} \sim 250 \mu \mathrm{m}$ (中砂), $250 \mu \mathrm{m} \sim 125 \mu \mathrm{m}$ (細 砂), $125 \mu \mathrm{m} \sim 63 \mu \mathrm{m}$ (極細砂), $63 \mu \mathrm{m}$ 以下 （シルト・粘土）とした。

\section{3. 結果と考察}

\section{$3 \cdot 1$ 放射性セシウムの深度分布}

各調整池で得られた深度別放射性セシウム濃 度測定結果を Fig. 5 に示した。台風後調査時 点で福島原発事故から約 2 年半が経っていたが, 地表面から深さ $5 \mathrm{~cm}$ 以内に $95 \%$ 以上（地表 から $10 \mathrm{~cm}$ 媣さまで実測された放射性セシウ ムの合計に対する割合で算出）の放射性セシウ ムが含まれていることが確認された。Ivanov ら ${ }^{26)}$ はチェルノブイリ原発事故から 2 年後に, 土壤中の放射性物質の分析を行い, ${ }^{137} \mathrm{Cs} の$ $99 \%$ と ${ }^{90} \mathrm{Sr}$ の $92 \%$ が土壤表層から $5 \mathrm{~cm}$ まで に堆積していると報告している。また，福島原 発事故以降, 福島県内での土壤中放射能濃度に ついて複数の報告 ${ }^{27)-29)}$ があるが，深度 $5 \mathrm{~cm}$ 程 度までに $90 \%$ 以上の事故由来放射性セシウム が蓄積されている結果が多く示されている。

チェルノブイリ原発事故や福島原発事故以降,
国内外での研究報告 27)-30) によると, 除染, 耕 作等の土壌のかく乱が無ければ，放射能濃度の 深度分布は指数関数的な近似式(1)が仮定でき るとされている。近似式において放射性物質の 地中への浸透の程度を表すパラメータとして緩 衝深度 $\alpha$ が知られており，放射能濃度が地表 の $37 \%$ (1/e 倍)になる深さと定義されている。

$$
C(z)=C(0) \cdot \exp (-z / \alpha)
$$

ここで, $C(z)$ : 深さ $\mathrm{z}$ での放射性セシウム 濃度 $(\mathrm{kBq} / \mathrm{kg}), C(0)$ : 地表面での放射性セ シウム濃度 $(\mathrm{kBq} / \mathrm{kg}), \mathrm{z}$ : 深さ $(\mathrm{cm})$ である。 計測された土壤中放射性セシウム濃度の深度分 布の実測值から，最小自乗法によって $\alpha$ 值を 算出した。

梅雨後調查で，各調査場所で採取した 3 試料 から計測された $\alpha$ 值は柏 1 で $1.2 \sim 1.9 \mathrm{~cm}$, 柏 2 で $1.2 \sim 1.3 \mathrm{~cm}$, 松 10 で $1.1 \sim 1.2 \mathrm{~cm}$ であり，台風後調査で計測された $\alpha$ 值は柏 1 で $1.6 \sim 2.7 \mathrm{~cm}$, 柏 2 で $1.1 \sim 1.4 \mathrm{~cm}$, 松 10 で $1.0 \sim 1.2 \mathrm{~cm}$ であった。この結果から，同 一調査場所での地点間による放射性セシウムの 浸透性のばらつきは小さいことが分かった。

各調査期間で採取した 3 試料の各深度層にお 


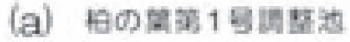

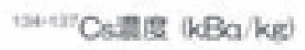

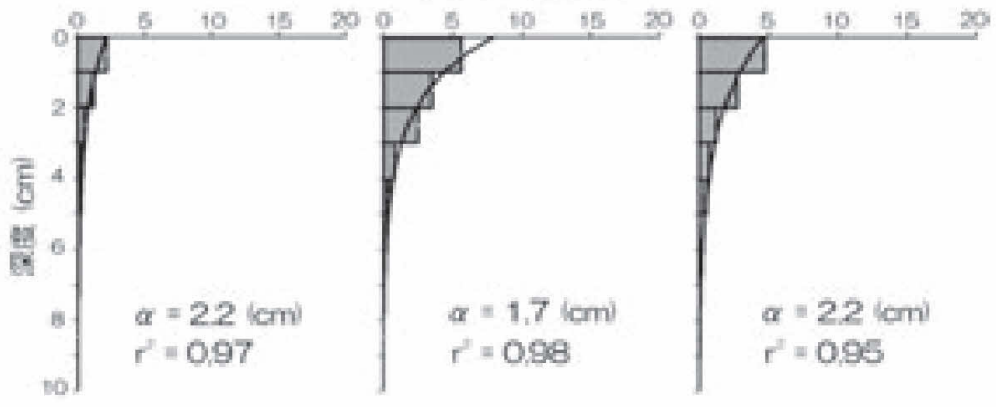

(b)
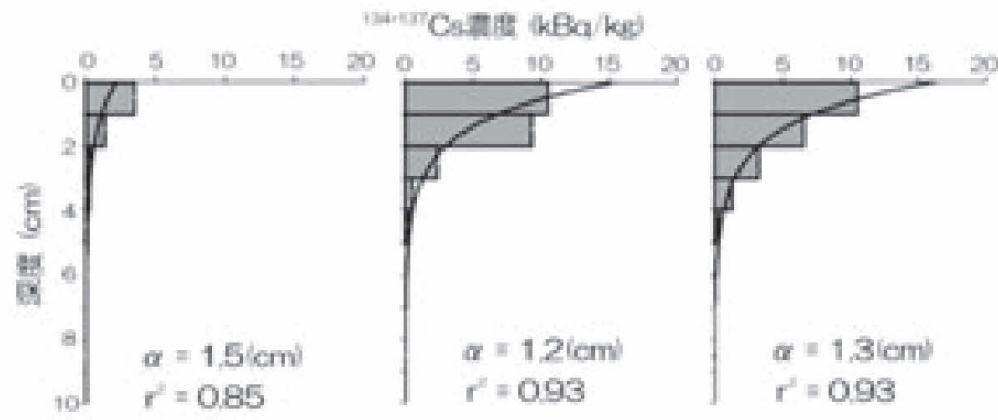

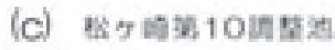

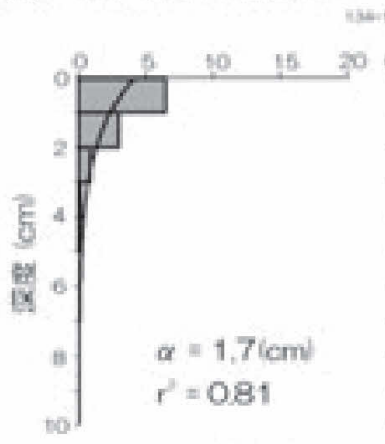

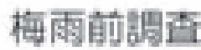

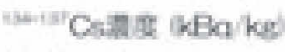

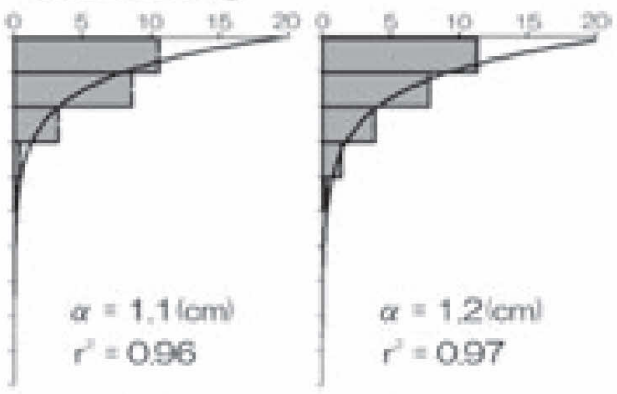

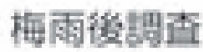

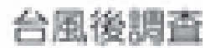

Fig. 5 調查期間を通じて各調整池の敷地内で採取した土壌中放射性セシウム 平均濃度の経時変化

ける放射性セシウムの平均濃度より得られた $\alpha$ 值は Table 1 のとおりで，梅雨前 $\rightarrow$ 梅雨後 $\rightarrow$ 台 風後の期間中の降雨によって放射性セシウムの
浸透の進展を評価した。この結果から，全ての 調査場所において $\alpha$ 值に大きな変動が認めら れず，また放射性セシウムの絶対值もそれほど 
Table 1 各調查場所・調查時期で放射性セシウムの深度分布から算出された $\alpha$ 值

\begin{tabular}{|c|c|c|c|}
\hline \multirow{2}{*}{ 調査地 } & \multicolumn{3}{|c|}{$\alpha$ 值 $(\mathrm{cm})$} \\
\hline & 梅雨前調查 ${ }^{*}$ & 梅雨後調查 ${ }^{* * *}$ & 台風後調查米米 \\
\hline 柏 1 & 2.2 & $1.7 \pm 0.4$ & $2.2 \pm 0.6$ \\
\hline 柏 2 & 1.5 & $1.2 \pm 0.1$ & $1.3 \pm 0.2$ \\
\hline 松10 & 1.7 & $1.1 \pm 0.1$ & $1.2 \pm 0.2$ \\
\hline \multicolumn{4}{|c|}{$\begin{array}{l}\text { 米各調査場所で採取した } 3 \text { 試料の土壌を } 2 \cdot 3 \text { に記載した深度幅で切り分けた各層の } \\
\text { 混合したものの測定值を記載。 }\end{array}$} \\
\hline \multicolumn{4}{|c|}{$\begin{array}{l}\text { 米米各調查場所で採取した } 3 \text { 試料の土壌を個々に } 2 \cdot 3 \text { に記載した深度幅で切り分け } \\
\text { た測定值から得られた「平均值士標準偏差」を記載。 }\end{array}$} \\
\hline
\end{tabular}

変化していないことから，放射性セシウムの浸 透はほとんど進んでいないと考えられた。

Matsunaga $ら^{299}$ は 2011 年の雨期前後にて, 福島県内の畑地, 芝地, 林地の土壤中放射性セ シウムの挙動を調查し, 降雨による放射性セシ ウムの浸透は確認されなかったと報告しており， 本調查結果と合致する結果であった。また, Rosen ら ${ }^{31}$ はスウェーデン国内で特性の異なる複 数の土壤を対象に 1987 年から 1995 年まで調查 し, 放射性セシウムの鉛直方向への浸透速度は チェルノブイリ原発事故から 1 年の期間内では $0.5 \sim 1.0 \mathrm{~cm} / \mathrm{y}$ ，それ以降は $0.2 \sim 0.6 \mathrm{~cm} / \mathrm{y}$ と算定しており, 放射性物質のフォールアウト から 1 年以上が経つと浸透速度は遅いと解析し ている。

一般的に放射性セシウムは, 土壌中の負に帯 電した有機物や粘土鉱物と親和性を有しており， 時間の経過とともに粘土鉱物のフレイド・エッ シ・サイト（以下，「FES」とする。雲母類の 風化により層間が膨潤した鉱物における膨潤層 と非膨潤層との境界に位置するくさび形に開い た部分）に特異的に吸着され, 下層土壌への浸 透が極めて小さくなるという研究報告がある ${ }^{32)}$ 。 このことから, 原発事故から約 $2 \sim 3$ 年が経過 した時点でも, FES に放射性セシウムが特異 的に吸着しており, 鉛直方向への移行が起こり にくくなっている可能性がある。だが, 第 4 次 分布状況等調查結果 ${ }^{1)}$ によると, 福島県, 宮城
県南部及び茨城県北部の調查地点ではある哚さ にピークを持つ深度分布が 2011 年 12 月以降か ら観察されており，今後も放射性セシウムの下 部方向への浸透の有無を確認する必要がある。

同一調查場所で採取した 3 試料における放射 能濃度の表層等における放射能濃度 (深さ $5 \mathrm{~cm}$ までの放射性セシウムの合計值）からばらつき を見るために変動係数を算出したところ，梅雨 後調査では柏 1 で $46 \%$, 柏 2 で $22 \%$, 松 10 で $45 \%$ ，台風後調查では柏 1 で $36 \%$ ，柏 2 で $18 \%$, 松 10 で $54 \%$ となり，比較した試料数は少ない が，同一調查場所で採取した土壌であるにもか かわらず水平分布のばらつきは大きかった。分 布状況等調査でも, 計 2200 の調査地点におい て $3 \mathrm{~m} \times 3 \mathrm{~m}$ 四方の範囲内で採取された 5 試料 の土壤中放射能濃度のばらつきを変動係数で評 価しており，平均で $36 \%$ のばらつきが確認さ れ, 調查場所によっては $100 \%$ を超えた場合も

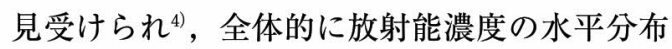
のばらつきは大きいと考えられている。本調査 結果並びに国の調査結果を受けて, 放射性セシ ウムの水平分布について評価するための補足調 查を行った。その調査内容については $3 \cdot 4$ 節で 解説する。

\section{$3 \cdot 2$ 放射性セシウムの土壌沈着量}

計測された放射性セシウム濃度の深度別デー 夕と土壤密度から，各層の放射性セシウム土壤 
Table 2 採取した土壤から見積もられた各調查場所における放射性セシウム沈着量

\begin{tabular}{|c|c|c|c|c|}
\hline \multirow[b]{2}{*}{ 調查地 } & \multicolumn{4}{|c|}{ 放射性セシウム沈着量 $\left(\mathrm{kBq} / \mathrm{m}^{2}\right)$} \\
\hline & 2012年3月 1 日 & $\begin{array}{c}\text { 梅雨前調查 } \\
\text { 2013年5月23日 }\end{array}$ & $\begin{array}{c}\text { 梅雨後調查 } \\
\text { 2013年7月12日 }\end{array}$ & $\begin{array}{c}\text { 台風後調查 } \\
\text { 2013年11月27日 }\end{array}$ \\
\hline 柏1 & & 20 & 66 & 57 \\
\hline 柏 2 & & 21 & 73 & 79 \\
\hline 松10 & & 68 & 131 & 82 \\
\hline in-situ ${ }^{*}$ & 100 & 84 & 82 & 79 \\
\hline $\begin{array}{l}\text { 米可搬型今 } \\
\text { 厶沈着量㕶 } \\
2012 \text { 年3月1 } \\
\text { ては 3月1 }\end{array}$ & 三ウム半導体 & $\begin{array}{l}\text { 出器を用いたi } \\
\text { プに公表されて } \\
\text { ナる換算値で女 } \\
\text { 扵壊変の式で算 }\end{array}$ & $\begin{array}{l}\text { itu測定で得られ } \\
\text { る。本表で引用 } \\
\text { その他の年月 } \\
\text { た。 }\end{array}$ & $\begin{array}{l}\text { た放射性セシウ } \\
\text { ている值は、 } \\
\text { の沈着量につい }\end{array}$ \\
\hline
\end{tabular}

沈着量 $\left(\mathrm{kBq} / \mathrm{m}^{2}\right)$ を算出した ${ }^{27)}$ 。各調整池の 放射性セシウム $\left({ }^{134} \mathrm{Cs}\right.$ と ${ }^{137} \mathrm{Cs}$ の合計) の沈着 量 (地表面から深さ $5 \mathrm{~cm}$ までの合計) は Table 2 のとおりである。放射線量等分布マップ (2012 年 12 月 28 日時点のモニタリング結果）では, 可搬型ゲルマニウム半導体検出器を用いた insitu 測定による放射性セシウムの沈着量 ${ }^{33)}$ が公 表されており，当該調査区域周辺での放射性セ シウムの沈着量は 2012 年 3 月 1 日換算で 100 $\mathrm{kBq} / \mathrm{m}^{2}\left({ }^{134} \mathrm{Cs}: 43 \mathrm{kBq} / \mathrm{m}^{2},{ }^{137} \mathrm{Cs}: 57 \mathrm{kBq} / \mathrm{m}^{2}\right)$ とされている。この in-situ 測定結果について, 物理的半減期のみによる減衰（風雨などの環境 要因による減衰であるウェザリング効果は加味 しない）から算出された沈着量についても本調 查結果と比較するために Table 2 に記載した。 各期間の本調查結果と in-situ 測定結果は, 近 似した箇所もあったが，相違する箇所もあった (例えば, 梅雨前調査の柏 1 と柏 2 , 梅雨後調 查の松 10)。このようにin-situ の結果と相違し た箇所では，上記のとおり土壌に沈着した放射 性セシウムの水平分布の不均一性が起因してい る可能性がある。

$3 \cdot 3$ 放射性セシウムと土壤粒子径について

深度別放射性セシウム濃度の測定が完了した 後に，0〜 $5 \mathrm{~cm}$ までの層を十分混合した土壤 試料を $2 \cdot 5$ 節で記載した幅で分級した。各画分
における放射性セシウム濃度を Fig. 6 に示し たが，放射性セシウム濃度に明確な粒径依存性 は確認されなかった。山西ら ${ }^{34)}$ が福島県内の小 中学校を中心に土壤中放射性セシウム濃度につ いて調查した際, Fig.7 (a) (日本アイソトープ 協会より転載の許可取得済み）に示したように， 乾式ふるい法で土壤粒子を分級した場合, 粗い 粒子に細かい粒子が付着していたため粒度によ る放射性セシウム濃度の差が小さかったが，土 㙴粒子を水洗いしたところ粒径の細かい粒子側 で放射性セシウム濃度が高い傾向を示したと報 告している。本調査においても, 水洗いを行い ながらの湿式灾るい法によって分級し，各分画 における放射性セシウム濃度を Fig. 7(b)に示 したように定量したが，乾式ふるい法で得られ た結果とほぼ同じであった。

\section{$3 \cdot 4$ 放射性セシウムの水平分布}

放射性物質は同一調査場所においても，土地 利用状況, 地形状況, 周辺の植栽等の障害物, 風雨による移動などさまざまな要因によって水 平方向に不均一な分布を持つと考えられている。 しかし, 実際に水平分布について定量的に検証 を行った調查事例は少ない。

我々は，平坦地で周辺に樹木等の植物が無く かつ除染作業が行われていない立地条件で一定 範囲の面積を有する松 10 の土壤採取区域（約 


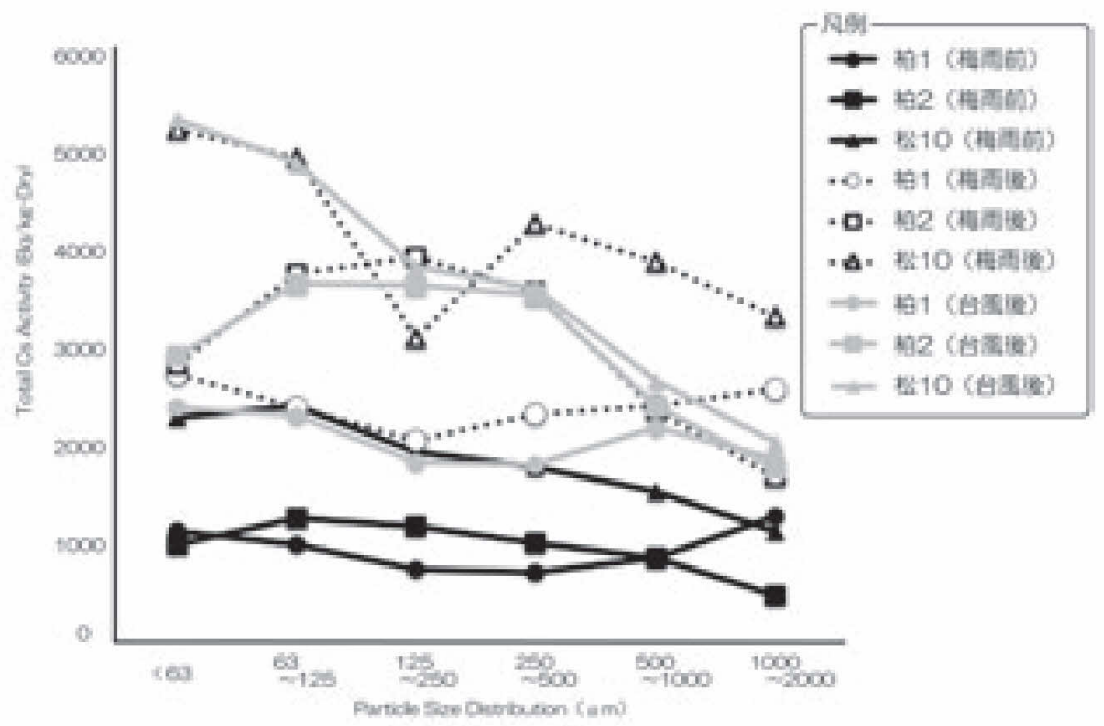

Fig. 6 乾式ふるい法で分級した土壌の各分画における放射性セシウム濃度

$\left.150 \mathrm{~m}^{2}\right)$ を調查対象とし，2014 年 3 月 18 日に 水平分布の検証を行った。Fig. 8 に示したよう な松 10 の調査地で $1 \mathrm{~m}$ 間隔で, Fig.9のよう な円柱型の厚さ $5 \mathrm{~cm}$ の鉛の遮蔽体の孔にエネ ルギー補償型 $\mathrm{NaI}(\mathrm{Tl})$ シンチレーション式サー ベイメー夕（日立アロカメディカル TCS-172 B）を差し込み地面直下から放出される $\gamma$ 線の 計数率（cps）を計 33 地点で計測した。鉛の遮 蔽体はサーベイメー夕を孔に差し込んだときに, 先端の検知部が地表面から高さ $1 \mathrm{~cm}$ になるよ うに設計した。計測方法は, 時定数を 10 秒と し同一地点で得られた計 5 回の計測值の相加平 均値を求めた。また，同一形状の円柱型の鉛の 遮蔽体で中心部の孔が下から $5 \mathrm{~cm}$ の高さで塞 がれているものを使用し，測定開始前にその鉛 の遮蔽体の孔にサーベイメータを差し込み周辺 環境からの $\gamma$ 線が計数されていないことを確 認した。

33 地点の地表面から計測された $\gamma$ 線の計数 率の頻度分布を Fig. 10 に示した。平坦な同一 区域内であるにもかかわらず，計数率に地点間 差が確認され, 地点によっては $2 \sim 3$ 倍程度の 差が計測された。計数率で $14 \mathrm{cps}, 20 \mathrm{cps}, 30$ cps が計測された調査地点を代表値として選定 しそれぞれLow, Mid, High とした。計数率 の計測を行った同日に，それぞれの土壤をハン ドサンプラーでコア状に採取し放射性セシウム 濃度を定量した。その結果はFig. 11 の通りで， $\alpha$ 值は $1 \mathrm{~cm}$ 前後で地点による顕著な差がほと

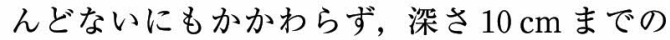
放射性セシウムの合計值は Low : $6.8 \mathrm{kBq} / \mathrm{kg}$, Mid : $14.7 \mathrm{kBq} / \mathrm{kg}$, High : $18.6 \mathrm{kBq} / \mathrm{kg}$ となり, 計数率の計測結果と同様で放射性セシウム濃度 においても地点によっては $2 \sim 3$ 倍程度の水平 分布があることがわかった。

\section{$3 \cdot 5$ 関東ロームの特異性}

土畩や底泥等の粒子状物質において, 粒径サ イズが小さいほど単位重量あたりの表面積が大 きくなるため, 放射性セシウムとの面的な吸着 量が多くなり，結果として放射性セシウム濃度 が大きくなることを示すデータがこれまでにチ エルノブイリ原発事故後や福島原発事故後の調 查で報告 1 (1)-4),27),35),36)されている。しかし，本調 査では上記のとおり土壤中の放射性セシウム濃 度に明確な粒径依存性は確認されなかった。 
(a)

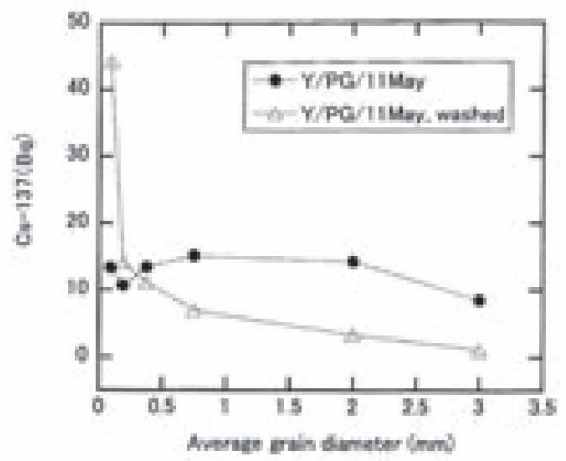

(b)

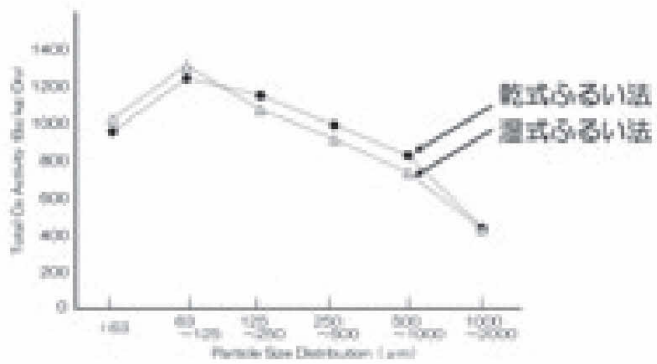

Fig.7 同一土壤を乾式ふるい法と湿式ふるい法で 分級した各分画の放射性セシウム濃度の比 較。(a) 山西ら ${ }^{34)}$ が福島県内の土壤で得ら れた結果 (転載図)，(b) 著者らが柏市の 土壤で得られた結果

放射性セシウム濃度が粒径依存性を示さなか ったことに関して，著者らは関東地方特有の火 山灰性土である関東ロームに着目をした。柏市 は, 北総台地の中央部に位置しており，本調査 が行われた調査地点は関東ローム層の堆積する 乾いた土地である ${ }^{37)}$ (本調査地においても地質 学専門家が関東ロームであることを確認)。飯 竹ら ${ }^{38}$ が実施した土粒子の基礎研究から，土粒 子の物理化学的性質は比表面積やポアー（孔） 分布と深い関連性を示していることが示されて いる。特に関東ロームは, Fig. 12（土木学会 より転載の許可取得済み)に示したように $5 \mathrm{~nm}$ 以下のポアーが多く, $2 \mathrm{~nm}$ でピークを示して いることから他の土と比べてミクロポアーの多

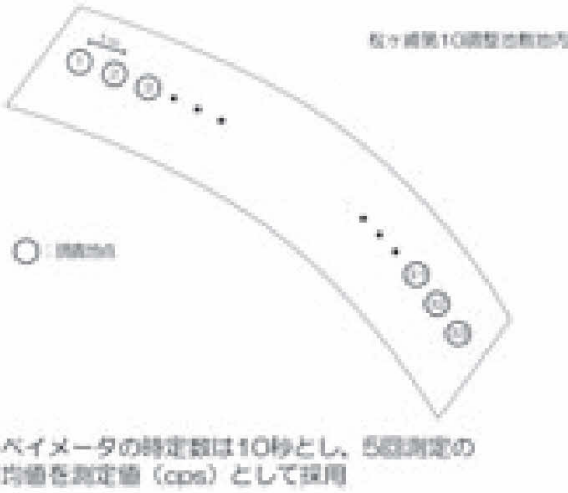

Fig. 8 補足調查として放射性セシウムの水平分布 の検証を実施した松 10 敷地内の調查地点

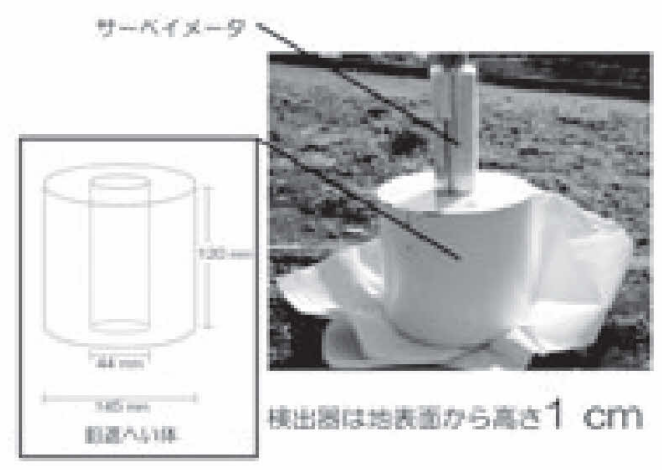

Fig.9 地面直下から放出される $\gamma$ 線の計測方法

い多孔質構造であり，他の土と比べて特異な性 状を示すデータが示された。推察の域を出ない が, 関東ロームは特異的な多孔質構造を持ち単 位重量あたりの表面積が大きくなることから， 本調査で採取した土壤では放射性セシウムの粒 径依存性が確認されなかったのかもしれない。 関東ロームと放射性セシウムの関連性について は, 別の専門的な切り口からの解析の必要性が ある。

\section{4. まと め}

降雨による土壌中放射性セシウムの移行状況 を確認するために，手賀沼水系の支流である大 堀川を流未とする千葉県柏市内の雨水調整池 3 


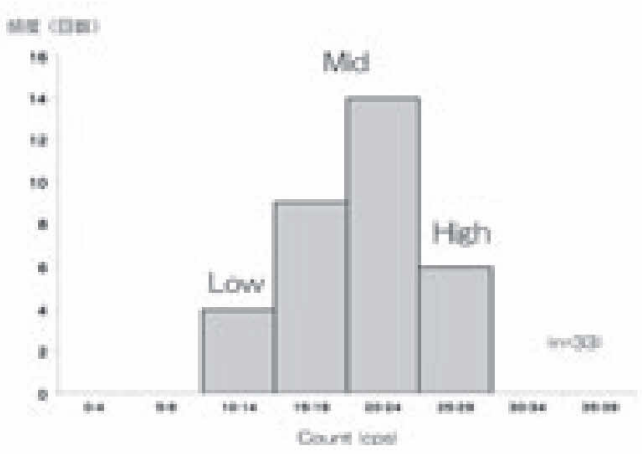

Fig. 10 同一調查地の計 33 地点の地表面から計測 された $\gamma$ 線計数率 $(\mathrm{cps})$ の頻度分布
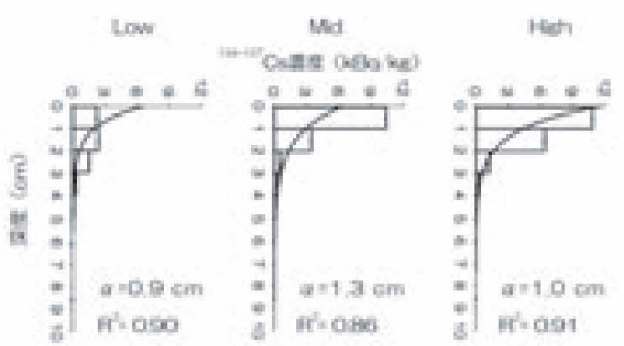

6.8 whind

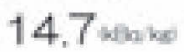

18.6 whinge

Fig. 11 計数率の異なる地点 (Low, Mid, High) の土壤中における放射性セシウム濃度

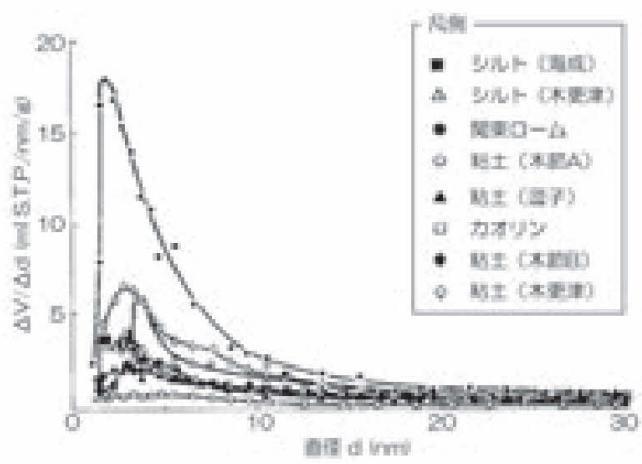

Fig. 12 土の種類とポアー分布 (飯竹ら ${ }^{38)}$ の転載 図)

か所で採取した土壌を対象に調査を行った。 2013 年度の梅雨期前後と台風後に調査時期を
設定し，放射性セシウムの深度分布を経時的に モニタリングすると共に, 水平方向の分布につ いても検証した。本調查は, 福島原発事故から 約 $2 \sim 3$ 年後に実施され, 深度別の土壌中放射 性セシウム濃度の測定より, 地表面から深さ 5 $\mathrm{cm}$ 以内に $95 \%$ 以上の放射性セシウムが含ま れていることが確認された。また，降雨による 土壤中放射性セシウムの鉛直方向への浸透状況 を緩衝深度で検証したところ，浸透はほとんど 進行していないことが示唆された。土壤中放射 性セシウムの水平分布については, ばらつきが 大きく, 同一䋯地内でも地点によっては最大で $2 \sim 3$ 倍程度の差があることがわかった。本調 査では, 土壤を乾式ふるい法並びに湿式ふるい 法で分級し，画分別に放射性セシウム濃度を計 測したが粒径依存性は確認されなかった。この 要因として, 関東地方特有の火山灰性土である 関東ロームの特異的な多孔質構造 $(5 \mathrm{~nm}$ 以下 のミクロポアーが多い構造）が関与している可 能性がある。

\section{文献}

1）日本原子力研究開発機構：原子力規制庁委託事 業「平成 25 年度東京電力 (株) 福島第一原子力 発電所事故に伴う放射性物質の長期的影響把握 手法の確立事業」成果報告書 (2014)

2) 日本原子力研究開発機構 : 平成 24 年度放射能測 定調査委託事業「福島第一原子力発電所事故に 伴う放射性物質の長期的影響評価手法の確立」 成果報告書 (2013)

3）日本原子力研究開発機構：平成 23 年度放射能測 定調查委託事業「福島第一原子力発電所事故に 伴う放射性物質の第二次分布状況等に関する調 查研究」成果報告書 (2012)

4）文部科学省：東京電力福島第一原子力発電所の 事故に伴い放出された放射性物質の分布状況等 に関する調查研究結果 (2011)

5）環境省：千葉県内の公共用水域における放射性 物質モニタリングの測定結果について, 平成 23 年 12 月 22 日

6）環境省: 千葉県, 埼玉県及び東京都内の公共用 水域に拐ける放射性物質モニタリングの測定結 
果について (2 回目), 平成 24 年 3 月 30 日

7）環境省：千葉県, 埼玉県及び東京都内の公共用 水域における放射性物質モニタリングの測定結 果について（5月-6月採取分)，平成 24 年 7 月 31 日

8）環境省：千葉県，埼玉県及び東京都内の公共用 水域における放射性物質モニタリングの測定結 果について（7月-9月採取分)，平成 24 年 10 月 11 日

9）環境省：千葉県，埼玉県及び東京都内の公共用 水域における放射性物質モニタリングの测定結 果について $(9$ 月- 11 月採取分), 平成 25 年 1 月 10 日

10）環境省：千葉県, 埼玉県及び東京都内の公共用 水域における放射性物質モニタリングの測定結 果について (12 月- 2 月採取分), 平成 25 年 3 月 29 日

11）環境省：千葉県，埼玉県及び東京都内の公共用 水域における放射性物質モニタリングの測定結 果について（5月-6 月採取分)，平成 25 年 8 月 9 日

12）環境省：千葉県，埼玉県及び東京都内の公共用 水域に打ける放射性物質モニタリングの测定結 果について $(7$ 月 -9 月採取分)，平成 25 年 11 月 8 日

13）環境省：千葉県，埼玉県及び東京都内の公共用 水域における放射性物質モニタリングの測定結 果について（10 月- 11 月採取分)，平成 26 年 1 月 16 日

14）環境省：千葉県，埼玉県及び東京都内の公共用 水域における放射性物質モニタリングの測定結 果 (速報) (1月-2月採取分), 平成 26 年 3 月 7 日

15）環境省：千葉県，埼玉県及び東京都内の公共用 水域における放射性物質モニタリングの测定結 果 (速報) (5 月- 7 月採取分), 平成 26 年 7 月 31 日

16）千葉県：手賀沼・印旛沼流域における水質 - 底 質の放射性物質モニタリング調査結果（速報値 - 手賀沼流域), 平成 24 年 7 月 3 日報道発表資 料

17）千葉県：手賀沼・印旛沼流域における水質・底 質の放射性物質モニタリング調查結果 (2 回目), 平成 25 年 2 月 27 日報道発表資料

18）千葉県：手賀沼・印旛沼流域における水質・底
質の放射性物質モニタリング調查結果（3 回目), 平成 25 年 4 月 30 日報道発表資料

19）千葉県：手賀沼・印旛沼流域における水質・底 質の放射性物質モニタリング調查結果（平成 25 年度 1 回目), 平成 25 年 9 月 3 日報道発表資料

20）千葉県：手賀沼・印旛沼流域に打ける水質・底 質の放射性物質モニタリング調査結果（平成 25 年度 2 回目)，平成 25 年 10 月 29 日報道発表資 料

21）千葉県：手賀沼・印旛沼流域における水質・底 質の放射性物質モニタリング調查結果（平成 25 年度 3 回目), 平成 26 年 1 月 31 日報道発表資料

22）千葉県：手賀沼・印旛沼流域に抢ける水質 - 底 質の放射性物質モニタリング調查結果（平成 25 年度 4 回目), 平成 26 年 5 月 30 日報道発表資料

23）千葉県：手賀沼・印旛沼流域に扔ける水質・底 質の放射性物質モニタリング調査結果（平成 26 年度 1 回目), 平成 26 年 8 月 19 日報道発表資料

24）気象庁ホームページ：過去の気象デー夕検索, http : //www.data.jma.go.jp/obd/stats/etrn/index.php

25）消防庁応急対策室，平成 25 年台風第 26 号によ る被害状況等について (第 36 報)，平成 25 年 11 月 26 日

26) Ivanov, Y. A., Lewyckyj, N., Levchuk, S. E., Prister, B. S., Firsakova, S. K., Arkhipov, N. P., Arkhipov, A. N., Kruglov, S. V., Alexakhin, R. M., Sandalls, J. and Askbrant, S., Migration of ${ }^{137} \mathrm{Cs}$ and ${ }^{90} \mathrm{Sr}$ from Chernobyl fallout in Ukrainian, Belarussian and Russian soils, J. Environ. Radioactiv., 35, 1-21 (1997)

27) Koarashi, J., Atarashi-Andoh, M., Matsunaga, T., Sato, T., Nagao, S. and Nagai, H., Factors affecting vertical distribution of Fukushima accidentderived radiocesium in soil under different landuse conditions, Sci. Total Environ., 431, 392-401 (2012)

28) Kato, H., Onda, Y. and Teramage, M., Depth distribution of ${ }^{137} \mathrm{Cs}$, ${ }^{134} \mathrm{Cs}$, and ${ }^{131} \mathrm{I}$ in soil profile after Fukushima Dai-ichi Nuclear Power Plant Accident, J. Environ. Radioactiv., 111, 59-64(2012)

29) Matsunaga, T., Koarashi, J., Atarashi-Andoh, M., Nagao, S., Sato, T. and Nagai, H., Comparison of the vertical distributions of Fukushima nuclear accident radiocesium in soil before and after the 
first rainy season, with physicochemical and mineralogical interpretations, Sci. Total Environ., 447, 301-314(2013)

30) Isaksson, M. and Erlandsson, B., Experimental determination of the vertical and horizontal distribution of ${ }^{137} \mathrm{Cs}$ in the ground, J. Environ. Radioactiv., 27 (2), 141-160 (1995)

31) Rosen, K., Oburn, I. and Lonsjo, H., Migration of radiocaesium in Swedish soil profiles after the Chernobyl accident, 1987-1995, J. Environ. Radioactiv., 46(1) , 45-66(1999)

32）山口紀子, 高田祐介, 林健太郎, 石川 覚, 倉 俣正人, 江口定夫, 吉川省子, 坂口 敦, 朝田 景, 和頴朗太, 牧野和之, 赤羽幾子, 平舘俊太 郎, 土壤一植物系における放射性七シウムの挙 動とその変動要因, 農業環境技術研究所報告, 31, 75-129(2012)

33）放射線量等分布マップ拡大サイト, http : //ramap.jaea.go.jp/map/

34）山西弘城, 芳原新也, 若林源一郎, 稲垣昌代, 堀口哲男, 小島 清, 野間 宏, 杉浦紳之, 古 川道郎, 伊藤哲夫, 福島県川俣町における環境 放射線調查一土壤中放射性セシウム濃度一, $R A$ DIOISOTOPES, 62, 259-268(2013)

35) He, Q. and Walling, D. E., Interpreting particle size effects in the adsorption of ${ }^{137} \mathrm{Cs}$ and unsupported ${ }^{210} \mathrm{~Pb}$ by mineral soils and sediments, $J$. Environ. Radioactiv., 30 (2), 117-137(1996)

36）田林 雄, 山室真澄, 霞ヶ浦流入河川堆積物に おける粒径と放射性セシウム濃度の関係, 陸水 学雑誌, 74, 183-189(2013)

37）柏市, 柏市環境基本計画 第 2 章一環境の現状 と課題, 平成 21 年 3 月, http : //www.city.kashiwa.lg.jp/soshiki/080500/ p005354_d/fil/003.pdf
38）飯竹重夫, 金井太一, 関東ロームの粒子表面特 性とその工学的性質に及ほす影響について, 土 木学会論文報告集，328，69-76(1982)

\section{Abstract}

Investigation of the Vertical and Horizontal Distribution of Radioactive Caesium in the Soil of Kashiwa City, Chiba, Japan

Yujiro Ichikawa, Tomohiro Inoue, Suekazu NaIto, Tsutomu TANaka and Yoshihiko TAKahashi: Chiba Prefectural Environmental Research Center, 1-8-8 Iwasakinishi, Ichihara-shi, Chiba Perf. 290-0046, Japan

To investigate the migrate situation of radioactive cesium in the soil due to the rainfall, the soil was collected at Kashiwa City, Chiba, Japan, before and after rainy season and after the typhoon season of 2013 fiscal year. This research was conducted between a period of $2-3$ years passed since the accident of Fukushima Daiichi Nuclear Power Plant. More than $95 \%$ of radioactive caesium still remained in the first upper $5 \mathrm{~cm}$ soil layer. Also, penetration of radioactive caesium to the deeper layer of the soil was not observed during investigation period. In spite of same sampling area (within $150 \mathrm{~m}^{2}$ ), there were $2-3$ times of horizontal variations of radioactive caesium depending on sampling point. The soil collected in this study did not show dependent relation between the particle size distribution of the soil and the concentration of radioactive caesium. This phenomenon might be due to the cause of characteristic properties of Kanto Loam particles. 